\title{
Enhanced solubilization of insoluble silicate from quartz and zeolite minerals by selected Aspergillus and Trichoderma species
}

\author{
Peningkatan kelarutan silikat sukar larut asal mineral kuarsa dan zeolit oleh \\ spesies Aspergillus dan Trichoderma
}

Laksmita P. SANTI

Indonesian Research Institute for Biotechnology and Bioindustry Jl. Taman Kencana No.1 Bogor 16128, Indonesia

Diterima tgl 26 Mei 2020 / disetujui tgl 17 September 2020

\begin{abstract}
Abstrak
Silikon (Si) merupakan komponen utama yang terdapat pada partikel pasir, debu, dan klei tanah. Silika tersedia dalam bentuk asam silika $\left(\mathrm{H}_{4} \mathrm{SiO}_{4}\right)$ di dalam larutan tanah tergolong rendah, hanya pada kisaran 3,5-40,0 mg Si $L^{-1}$. Fungi pelarut silika (FPS) memiliki peran penting dalam meningkatkan ketersediaan silika sukar larut $\left(\mathrm{SiO}_{2}\right)$ di dalam tanah untuk tanaman. Tujuan dari penelitian ini untuk menetapkan potensi pelarutan silika dan produksi asam organik tujuh isolat FPS di dalam media Bunt dan Rovira dengan menggunakan 0,25\% (b/v) magnesium trisilika $\left(\mathrm{Mg}_{2} \mathrm{O}_{8} \mathrm{Si}_{3}\right)$, pasir kuarsa, dan zeolit sebagai sumber silika. Pengujian potensi FPS dilakukan dengan menggunakan rancangan acak lengkap dengan tiga perlakuan sumber silika dan tiga ulangan. Hasil penelitian menunjukkan bahwa seluruh FPS yang diuji memiliki kemampuan dalam menghasilkan asam asetat, sitrat, dan oksalat serta dapat meningkatkan kelarutan silika sukar larut. Trichoderma polysporum dan Aspergillus niger BCCF194 merupakan isolat terbaik fungi pelarut silika. Lebih lanjut diketahui pula terdapat korelasi positif yang sangat nyata $(p<0,05)$ antara kapasitas pelarutan silika di dalam medium Bunt dan Rovira dengan pasir kuarsa atau zeolit sebagai sumber silika terhadap waktu inkubasi $\left(R^{2}=0,79-0,99\right)$ dan produksi asam sitrat $\left(R^{2}=0,97-0,99\right)$ dari $\mathrm{T}$. polysporum dan A. niger $B C C F 194$.
\end{abstract}

[Kata kunci: Aspergillus niger, asam silika, fungi pelarut silika, Trichoderma polysporum]

\begin{abstract}
Silicon ( $\mathrm{Si}$ ) is a major component of sand, silt and clay particles of soils. Available silica as silicic acid $\left(\mathrm{H}_{4} \mathrm{SiO}_{4}\right)$ present in soil solution is considerably low, only in the range of $3.5-40.0 \mathrm{mg}$ $\mathrm{Si} \mathrm{L}^{-1}$. To improve plant-available $\mathrm{Si}$ in the soil, silicate-solubilizing fungi (SSF) are potentially
\end{abstract}

important in solubilizing insoluble forms of silicate $\left(\mathrm{SiO}_{2}\right)$. The objectives of this study were to determine silicate solubilizing capacity and organic acid produced by seven SSF isolates on Bunt and Rovira media by using $0.25 \%$ (w/v) magnesium trisilicate $\left(\mathrm{Mg}_{2} \mathrm{O}_{8} \mathrm{Si}_{3}\right)$, quartz, and zeolite as a silica source. Determination of SSF isolates potential in $\mathrm{Si}$ solubilization was carried out in a completely randomized design with three silica sources and three replicates. The results indicated that all SSF were capable of producing acetic, citrate, and oxalic acids and enhancing the solubilization of insoluble silicates. Trichoderma polysporum and Aspergillus niger BCCF194 were the best isolates of SSF. Furthermore, there was significantly $(p<0.05)$ positive correlation between solubilizing silicate capacity by using quartz or zeolite as a silica source on Bunt and Rovira media with incubation time $\left(\mathrm{R}^{2}=0.79-0.99\right)$ and citric acid production $\left(\mathrm{R}^{2}=0.97-0.99\right)$ from $T$. polysporum and A. niger BCCF194.

[Key words: Aspergillus niger, silicic acid, silicate-solubilizing fungi (SSF), Trichoderma polysporum]

\section{Introduction}

Silicon is the second most abundant constituent in the earth's crust, whereas the total elemental analysis of typical mineral soil is about $28 \%$ silicon and $47 \%$ oxygen thus majority is bonded with oxygen and other elements in the crystalline form in the mineral soil (Heckman, 2013). With weathering and time, some of this vast supply of silicon is released in soluble forms available for uptake by plants. Silicon release to soil solution from weathering of silicate-containing minerals is rather slow. Si adsorption/desorption on various solid phases, uptake and assimilation by plants and microorganisms, preservation of stable Si forms in the profile (Cornelis et al., 2011). The soil silica is normally present as polymerized form which because of biological or chemical reactions gets 
converted into water-soluble mono silicic acid, also called ortho silicic acid $\left(\mathrm{H}_{4} \mathrm{SiO}_{4}\right)$, absorbed by plants. Various studies have reported weathering of silicates by bacteria for its dissolution to make it available to the plants (Santi \& Goenadi, 2017; Chandrakala et al., 2019).

Improved Si management to increase yield and sustain crop productivity appears to be necessary in tropical countries, because the available $\mathrm{Si}$ in highly weathered soils such as in Indonesia might be limited. Silicon from natural sources has a potential to mitigate environmental stresses and soil nutrient depletion thereby maintaining sustainable agriculture (Guntzer et al., 2012) and accelerating growth, conferring rigidity to leaves thus maximizing leaf surface area for photosynthesis and mitigating the effects of abiotic stresses like drought, salt and metal toxicity in several plants (Naureen et al., 2015). Furthermore, Pei et al. (2010) indicated that Si might decreases the negative effects of oxidative stress and offers slight resistance to some abiotic and biotic plant stressors. Thus, using Si instead of herbicides and pesticides could reduce harmful environment effects (Vasanthi et al., 2012; Balakhnina \& Borkowska, 2013; Karmollachaab et al., 2013).

Wollastonite $\left(\mathrm{CaSiO}_{3}\right)$ is the best-known natural mineral as a Si fertilizer source. However, it is relatively expensive due to limited distribution (Haynes et al., 2013; Tubana et al., 2016). A laboratory incubation study was conducted by Babu et al. (2016) to evaluate the release pattern of $\mathrm{H}_{4} \mathrm{SiO}_{4}$ from wollastonite and Ca-silicate slag $(12 \% \mathrm{Si})$ applied to soils varying in clay content and chemical properties. They concluded that the amount of $\mathrm{H}_{4} \mathrm{SiO}_{4}$ measured in solution $(0.1 \mathrm{M}$ $\mathrm{NaCl}$ ) was influenced by the adsorption capacity of soils, which was highly determined by soil $\mathrm{pH}$, organic matter, and clay content.

In Indonesia, $\mathrm{Si}$ sources such as quartz from Bangka-Belitung Province (Santi et al., 2017) and zeolite from Bayah (Kalbuadi et al., 2019) are abundant and great interest for Si fertilizer in paddy, sugarcane, corn fields, and oil palm. However, the Si concentration in plants depends primarily on the concentration of silicic acid $\left(\mathrm{H}_{4} \mathrm{SiO}_{4}\right)$ in the soil solution and is not correlated to the total $\mathrm{Si}$ concentration of the soil. The dissolution and mobilization of silica in the soil by bacteria and fungus are well known. Moreover, solubilization of insoluble Si due to organic acid production by microbes is known to enhance their availability to plants. Silicate solubilizing bacteria have been reported by Santi \& Goenadi (2017) and have recently attracted great interest, since solubilization of silicate promotes the uptake of both $\mathrm{Si}$ and $\mathrm{K}$, thus reducing the need for potash fertilizer (Etesami et al., 2017) and phosphorus (P) (Lee et al., 2019). Daghino et al. (2010) reported that fungi, while degrading silica-based rocks can also release other mineral nutrients e.g. potassium, iron, and magnesium. The solubilization process by fungi occurs mainly via the production of organic acids and complexing agents and it is faster than that of bacteria. In vitro studies in our laboratory indicated that fungi were more efficient in the solubilization of silica as compared to bacteria (Santi et al., 2018). Thus, a very effective approach for silica solubilization in quartz and zeolite as silica sources is the application of fungi capable of excreting organic acid. The objectives of this study were to determine silicatesolubilizing capacity and organic acid produced especially citric acid by seven silica-solubilizing fungi (SSF) isolates, i.e.: Aspergillus niger strain K0909, BCCF194, A1601, Trichoderma sp., T. polysporum, T. pseudokoningii, and T. viride on Bunt and Rovira solid and liquid media by using magnesium trisilicate $\left(\mathrm{Mg}_{2} \mathrm{O}_{8} \mathrm{Si}_{3}\right.$ as control), quartz, and zeolite as a silica source.

\section{Materials and Methods}

A laboratory study was conducted in Microbiology and Environment Laboratory at Indonesian Research Institute for Biotechnology and Bioindustry (IRIBB), Bogor, in November 2018 - May 2019.

\section{Quartz mineral}

The mineral used was quartz type collected from Bangka-Belitung province containing 97.1$99.1 \% \mathrm{SiO}_{2}$ (Santi et al., 2017). The quarts analysis was conducted at Chemical Laboratory, IRIBB. Quartz sand samples were air dried and passed through 325 mesh sieve and analyzed for the following: $\mathrm{pH}$, total carbon (spectrophotometer), nitrogen (Kjeldahl), phosphorus (spectrophotometer), potassium (Atomic Absorption Spectrophotometer, AAS), magnesium (AAS), calcium (AAS), total $\mathrm{SiO}_{2}$ (gravimetry), sulphur, zinc, aluminum trioxide, iron trioxide, manganese dioxide, and cation exchange capacity (CEC) by using SNI 15-0346- 1989 standard method (Table 1).

\section{Zeolite mineral}

The natural zeolite of the clinoptilolite type $\left(\mathrm{Na}_{3} \mathrm{~K}_{3}\right)\left(\mathrm{Al}_{6} \mathrm{Si}_{30} \mathrm{O}_{72}\right) \cdot 24 \mathrm{H}_{2} \mathrm{O}$ from Bayah-BantenIndonesia origin, is one of the world's most abundantly available and widely used zeolitic minerals. Zeolite samples were air dried and passed through 150 mesh sieves and analyzed for the following: $\mathrm{pH}$, total carbon (spectrophotometer), nitrogen (Kjeldahl), phosphorus (spectrophotometer), potassium (Atomic Absorption Spectrophotometer, AAS), magnesium (AAS), calcium (AAS), total $\mathrm{SiO}_{2}$ (gravimetry), sulphur, zinc, aluminum trioxide, iron trioxide, manganese dioxide, and cation exchange capacity (CEC) by using SNI 13-3494-1994 standard method (Table 1). 
Table 1. Chemical characteristics of quartz and zeolite minerals

Tabel 1. Karakteristik kimia mineral kuarsa dan zeolit

\begin{tabular}{|c|c|c|c|c|c|}
\hline \multirow{2}{*}{$\begin{array}{c}\text { Chemical } \\
\text { characteristics } \\
\text { Karakteristik kimia }\end{array}$} & \multicolumn{2}{|c|}{$\begin{array}{c}\text { Results } \\
\text { Hasil }\end{array}$} & \multirow{2}{*}{$\begin{array}{c}\text { Chemical } \\
\text { characteristics } \\
\text { Karakteristik kimia }\end{array}$} & \multicolumn{2}{|c|}{$\begin{array}{c}\text { Results } \\
\text { Hasil }\end{array}$} \\
\hline & $\begin{array}{c}\text { Quartz } \\
\text { Kuarsa }\end{array}$ & $\begin{array}{c}\text { Zeolite } \\
\text { Zeolit }\end{array}$ & & $\begin{array}{l}\text { Quartz } \\
\text { Kuarsa }\end{array}$ & $\begin{array}{c}\text { Zeolite } \\
\text { Zeolit }\end{array}$ \\
\hline $\mathrm{pH}$ in $\mathrm{H}_{2} \mathrm{O}$ & 8.20 & 9.30 & $\mathrm{SiO}_{2}(\%)$ & 99.10 & 81.90 \\
\hline Carbon $(\%)$ & 0.12 & 0.21 & Available silica (ppm) & 0.80 & 3.53 \\
\hline Nitrogen $(\%)$ & 0.03 & 0.03 & Sulphur (ppm) & 86.00 & 0.95 \\
\hline $\mathrm{P}_{2} \mathrm{O}_{5}(\mathrm{ppm})$ & 30.10 & 0.04 & $\mathrm{Zn}(\mathrm{ppm})$ & 53.20 & 28.90 \\
\hline $\mathrm{K}_{2} \mathrm{O}(\%)$ & 0.01 & 0.74 & $\mathrm{Al}_{2} \mathrm{O}_{3}(\%)$ & 0.17 & 1.56 \\
\hline $\mathrm{MgO}(\%)$ & $<0.01$ & 0.18 & $\mathrm{Fe}_{2} \mathrm{O}_{3}(\%)$ & 0.03 & 0.41 \\
\hline $\mathrm{CaO}(\%)$ & 0.05 & 3.43 & $\mathrm{MnO}_{2}(\%)$ & $<0.01$ & 0.02 \\
\hline $\mathrm{Na}_{2} \mathrm{O}(\%)$ & $<0.01$ & 0.91 & $\mathrm{CEC}\left(\mathrm{cmol}^{+} / \mathrm{kg}\right)$ & 1.98 & 167.19 \\
\hline $\mathrm{Cr}_{2} \mathrm{O}_{3}(\%)$ & $<0.01$ & $<0.01$ & $\mathrm{TiO}_{2}(\%)$ & 0.02 & 0.20 \\
\hline
\end{tabular}

\section{Silicate-solubilizing fungi}

The seven isolates of silicate-solubilizing fungi (SSF) were studied previously regarding their ability to solubilize silicate in Burn and Rovira solid standard media inoculated with selected strains of Aspergillus i.e.: Aspergillus niger BCC F194, A. niger K0909 and A. niger A1601. Whereas, species of Trichoderma were Trichoderma sp., T. polysporum, $T$. viride, and $T$. pseudokoningii, respectively. These fungi were lodged at Microbiology and Environmental Laboratory, IRIBB, Bogor. As a source of inoculum, a piece of inoculant $\operatorname{SSF}(\varnothing=3 \mathrm{~mm})$ was grown on Bunt and Rovira solid medium as described by Vasanthi et al. (2013) consisting of $\left(\mathrm{L}^{-1}\right): 20 \mathrm{~g}$ glucose; $1.0 \mathrm{~g}$ peptone; $1.0 \mathrm{~g}$ yeast extract; $0.5 \mathrm{~g}\left(\mathrm{NH}_{4}\right)_{2} \mathrm{SO}_{4} ; 0.4 \mathrm{~g} \mathrm{~K}_{2} \mathrm{HPO}_{4} ; 0.1 \mathrm{~g}$ $\mathrm{MgCl}_{2} ; 0.01 \mathrm{~g} \mathrm{FeCl}_{3} ; 250 \mathrm{~mL}$ soil extract; $20 \mathrm{~g}$ oxoid agar; $750 \mathrm{~mL}$ tap water; $\mathrm{pH}$ 6.6-7.0. These media were supplemented with $0.25 \%$ magnesium trisilicate $\left(\mathrm{Mg}_{2} \mathrm{O}_{8} \mathrm{Si}_{3}\right)$ or modified medium using quartz sand and zeolite as sources of silicate.

\section{Silicate-solubilizing capacity}

For assessment in solid Bunt and Rovira medium, petri dishes containing Bunt and Rovira medium at each initial $\mathrm{pH}$ condition were inoculated with each culture strain of SSF. The culture dishes were incubated at $28^{\circ} \mathrm{C}$ for seven days. The diameter of the solubilization halo (translucent area surrounding colonies) was measured after 7 days incubation and the Solubilization Index (SI) expressed as halo diameter (mm)/colony diameter $(\mathrm{mm})$ was calculated (Akintokun et al., 2007). The investigated strains were classified based on their SI as demonstrating low ( $\mathrm{SI}<2.0)$, intermediate $(2.0 \leq \mathrm{SI}<4.0)$ and high $(\mathrm{SI} \geq 4.0)$ solubilization capacities.

Silica solubilizing capacity was assayed in $50 \mathrm{~mL}$ liquid and solid Bunt and Rovira medium with $0.25 \%(\mathrm{w} / \mathrm{v})$ insoluble magnesium trisilicate, quartz, and zeolite respectively. Inoculation was performed by transferring two pieces of inoculant ( $\varnothing=3 \mathrm{~mm} ; 10^{6}$ spores) on $250 \mathrm{~mL}$ Erlenmeyer flask containing $50 \mathrm{~mL}$ of liquid culture Bunt and Rovira medium. The cultures were incubated on a mechanical shaker at $100 \mathrm{rpm}\left(28^{\circ} \mathrm{C}\right)$ for 4,8 , and 12 days. Silica solubilizing capacities was determined by using American Standard Testing and Material (ASTM D859-16) method. The dissolved silicate in the form of silicic acid $\left(\mathrm{H}_{2} \mathrm{SiO}_{4}\right)$ was measured using a spectronic 21 spectrophotometer at $660 \mathrm{~nm}$ wavelength (Rinder \& Oelkers, 2014).

\section{Effect of organic acids on silica dissolution}

This experiment was carried out to clarify the relative strength of different types of organic acids in solubilizing silica from quartz sand and zeolite by using ASTM D859-16 method with colorimetric measurement. Citrate, acetate and oxalate were added separately in different concentrations $(0,100,200,300,400$, and 500 ppm) to $50 \mathrm{~mL}$ of Bunt and Rovira medium containing $0.25 \%(\mathrm{w} / \mathrm{v})$ quartz or zeolite, then incubated for eight days on a mechanical shaker at $100 \mathrm{rpm}$ in $28^{\circ} \mathrm{C}$. The dissolved silicate in the form of silicic acid $\left(\mathrm{H}_{2} \mathrm{SiO}_{4}\right)$ was measured using a spectronic 21 spectrophotometer at $660 \mathrm{~nm}$ wavelength (Rinder \& Oelkers, 2014).

Further, the SSF producing of organic acid was determined in liquid Bunt and Rovira with $0.25 \%$ $(\mathrm{w} / \mathrm{v})$ magnesium trisilicate, quartz sand and zeolite. Seven strains of SSF were grown in liquid Bunt and Rovira medium for 8 days, then incubated at a mechanical shaker at $100 \mathrm{rpm}$ in $28^{\circ} \mathrm{C}$. The type and concentration of organic acid produced by Aspergillus and Trichoderma species were determined on 8 days incubation as described by Jamal et al. (2005).

High-performance liquid chromatography (HPLC) Agilent HP Series 1100 was used to identify and quantify organic acids concentration in the culture with 8 days incubation. Samples 
were collected, filtered through a $0.45 \mu \mathrm{m}$ cellulose membrane, and injected into a Supelcogel C-610H $9 \mu \mathrm{m}$ chromatographic column sizing $30 \mathrm{~cm}$ x $7.8 \mathrm{~mm}$ (Marra et al., 2015).

\section{Effect of citric acid producing by SSF isolates on silica dissolution}

The SSF producing citric acid was determined in liquid Bunt and Rovira with $0.25 \%(\mathrm{w} / \mathrm{v})$ quartz and zeolite as sources of silica. Seven strains of SSF were grown in liquid Bunt and Rovira medium for 4,8 , and 12 days, then incubated at a mechanical shaker at $100 \mathrm{rpm}$ in $28^{\circ} \mathrm{C}$. Citric acid assay was done according to improved pyridineacetic anhydride acid method suggested by Marier and Boulet (Chetan et al., 2018). About $1 \mathrm{~mL}$ of pyridine and $5 \mathrm{~mL}$ of acetic anhydride added and incubated for $30 \mathrm{~min}$ in ice bath. The standard was prepared by different volumes of citric acid (100 mg of citric acid was dissolved in $100 \mathrm{~mL}$ of deionized water (DW), i.e.: $0.2-1 \mathrm{~mL}$ in 5 different test tubes. The volume was made up to $1 \mathrm{~mL}$ with DW. One milliliter of pyridine and $5 \mathrm{~mL}$ of acetic anhydride were added. The blank was prepared by taking $1 \mathrm{~mL}$ of DW in the place of citric acid. It was then kept for incubation in ice bath for 30 minutes. Concentration of citric acid was found by plotting graph of absorbance versus concentration and measured at $420 \mathrm{~nm}$ wavelength with the development of color density.

\section{Results and Discussion}

Silica originated from quartz and zeolite minerals

Selected chemical analysis showed that the quartz sand has alkaline reaction $\left(\mathrm{pH} \mathrm{H}_{2} \mathrm{O}-8.2\right)$ and mainly composed a high content of $\mathrm{SiO}_{2}$, and less of $\mathrm{Fe}_{2} \mathrm{O}_{3}, \mathrm{Al}_{2} \mathrm{O}_{3}, \mathrm{TiO}_{2}$, and $\mathrm{K}_{2} \mathrm{O}$ (Table 1). Quartz sand obtained has a good quality with a cadre of over $99.1 \%$ total $\mathrm{SiO}_{2}$. The result of this analysis showed that impurities usually present in the quartz sand were free and coated iron oxides, aluminum, and smaller amounts of magnesium, potassium and calcium minerals. According to Klein \& Philpotts (2013), quartz has a specific crystalline form (hexagonal), thus physically and chemically resistant to weathering. Furthermore, a zeolite sample has alkaline reaction $\left(\mathrm{pH} \mathrm{H}_{2} \mathrm{O}=\right.$ 9.3) and been characterized by high values of $\mathrm{SiO}_{2}$ and CEC (Table 1). Bai et al. (2019) studied that zeolite form have many different crystalline structures, which have large open pores (sometimes referred to as cavities) in a very regular arrangement and roughly the same size as small molecules.

\section{Silicate-solubilizing capacity}

Numerous field studies have shown that supplying crops with adequate plant-available $\mathrm{Si}$ (mono-poly-silicic acid) can suppress plant disease, reduce insect attack, improve environmental stress, and increase crop productivity. For the purpose of supplying silica in the form of silicic acid $\left(\mathrm{H}_{4} \mathrm{SiO}_{4}\right)$ for plant, there is a growing interest in the effectiveness of bacteria and fungi as mineral weathering agent (Santi \& Goenadi, 2012; Goenadi \& Santi, 2013; Kang et al., 2017). Microorganisms are the principal bioweathering agents and contribute to soil arrangement by providing supplements, such as $\mathrm{P}$, $\mathrm{K}$, and $\mathrm{Si}$, which bolster plant development (Bin et al., 2019). Different groups of researchers have developed the liquid screening media containing different silicon sources i.e.: feldspar, muscovite, biotite, and magnesium trisilicate (Santi \& Goenadi, 2017; Vasanthi et al., 2018).

In these research, three strains of Aspergillus and four species of Trichoderma were selected in order to search the highly potential of SSF for solubilizing silicate originated from quarts and zeolite. All the seven SSF were studied previously regarding their ability to solubilize silica in Bunt and Rovira solid medium using magnesium trisilicate $\left(2 \mathrm{MgO} .3 \mathrm{SiO}_{2}\right)$ as a basic of silica source (Vasanthi et al., 2018). The highest diameter of clear zone in Bunt and Rovira solid medium after 7 days incubation was observed for $T$. polysporum and Trichoderma sp. These diameters were categorized as a high solubilization index (SI).

Both of Aspergillus and Trichoderma species have the ability to solubilize silica from initial sources of magnesium trisilicate $\left(\mathrm{Mg}_{2} \mathrm{O}_{8} \mathrm{Si}_{3}\right)$ in Bunt and Rovira liquid medium. Silicate solubilizing capacity increased at 12 days incubation time. The amount of Si solubilized from magnesium trisilicate was directly related to the incubation time. The ability to solubilize silica in Bunt and Rovira liquid medium by Trichoderma species was higher than Aspergillus (Table 2). Furthermore, silica solubilizing capacity of $T$. polysporum in 8- and 12-days incubation on Bunt and Rovira liquid medium was less than $T$. viride and T. pseudokoningii. Results of this research indicated that no correlation between solubilizing silicate capacity and solubilization zone on solid Bunt and Rovira medium by using magnesium trisilicate as a silica source (Vasanthi et al., 2013).

Aspergillus and Trichoderma species also have ability to solubilize $\mathrm{SiO}_{2}$ from initial sources of quartz sand (Bangka-Belitung province) and zeolite from Bayah, Banten. These isolates grew well with variety of mycelia colors as response on different source of silica on solid Bunt and Rovira media (Figure 1 \& 2). Quartz and zeolite have higher $\mathrm{SiO}_{2}$ content than magnesium trisilicate $\left(65 \% \mathrm{SiO}_{2}\right)$, i.e.: 99.1 and $81.9 \%$. All species of Aspergillus and Trichoderma have significantly $(\mathrm{p}<0.05)$ positive correlation with incubation time in solubilizing silica originated from quartz, $\mathrm{R}^{2}=0.79-0.88 \quad$ (Aspergillus), $\quad \mathrm{R}^{2}=0.80-0.99$ (Trichoderma) and from zeolite, $\mathrm{R}^{2}=0.94-0.98$ 
Table 2. The ability of SSF isolates in solubilizing silicate in a liquid and solid Bunt and Rovira medium using $0.25 \%$ magnesium trisilicate as a silica source

Tabel 2. Kemampuan fungi pelarut silika dalam melarutkan silika pada medium cair dan padat Bunt dan Rovira dengan menggunakan 0,25\% magnesium trisilikat sebagai sumber Si di dalam medium

\begin{tabular}{|c|c|c|c|c|}
\hline \multirow{3}{*}{$\begin{array}{c}\text { Silicate solubilizing } \\
\text { fungi (SSF) isolates } \\
\text { Isolat fungi pelarut } \\
\text { silika }\end{array}$} & \multicolumn{3}{|c|}{$\begin{array}{c}\text { Solubilizing silicate from } 2 \mathrm{MgO} .3 \mathrm{SiO}_{2}(\mathrm{ppm}) \\
\text { Kelarutan silika dari } 2 \mathrm{MgO} .3 \mathrm{SiO}_{2}(\text { ppm) }\end{array}$} & \multirow{3}{*}{$\begin{array}{l}\text { Solubilization Index (SI) } \\
\text { Indeks kelarutan (IK) } \\
7 \text { days incubation time } \\
\text { Masa inkubasi } 7 \text { hari }\end{array}$} \\
\hline & \multicolumn{3}{|c|}{$\begin{array}{l}\text { Incubation time (day) } \\
\text { Waktu inkubasi (hari) }\end{array}$} & \\
\hline & 4 & 8 & 12 & \\
\hline A. niger BCCF194 & $\left.45.0 \mathrm{~d}^{*}\right)$ & $52.3 \mathrm{~g}$ & $91.4 \mathrm{~g}$ & $2.1 \mathrm{~b}$ (intermediate) \\
\hline A. niger K0909 & $39.7 \mathrm{f}$ & $67.3 \mathrm{f}$ & $106.8 \mathrm{f}$ & $1.9 \mathrm{~b}$ (low) \\
\hline A. niger A1601 & $52.1 \mathrm{~b}$ & $72.8 \mathrm{~d}$ & $108.2 \mathrm{e}$ & $1.8 \mathrm{c}$ (low) \\
\hline T. polysporum & $51.7 \mathrm{c}$ & $75.0 \mathrm{c}$ & $110.0 \mathrm{~d}$ & 4.0 a (high) \\
\hline T. viride & $42.7 \mathrm{e}$ & $85.9 \mathrm{a}$ & $124.0 \mathrm{c}$ & $1.0 \mathrm{~d}$ (low) \\
\hline T. pseudokoningii & $38.2 \mathrm{~g}$ & $86.8 \mathrm{a}$ & $128.7 \mathrm{~b}$ & $2.0 \mathrm{~b}$ (intermediate) \\
\hline Trichoderma sp. & $53.9 \mathrm{a}$ & $68.3 \mathrm{e}$ & $130.1 \mathrm{a}$ & 4.0 a (high) \\
\hline
\end{tabular}
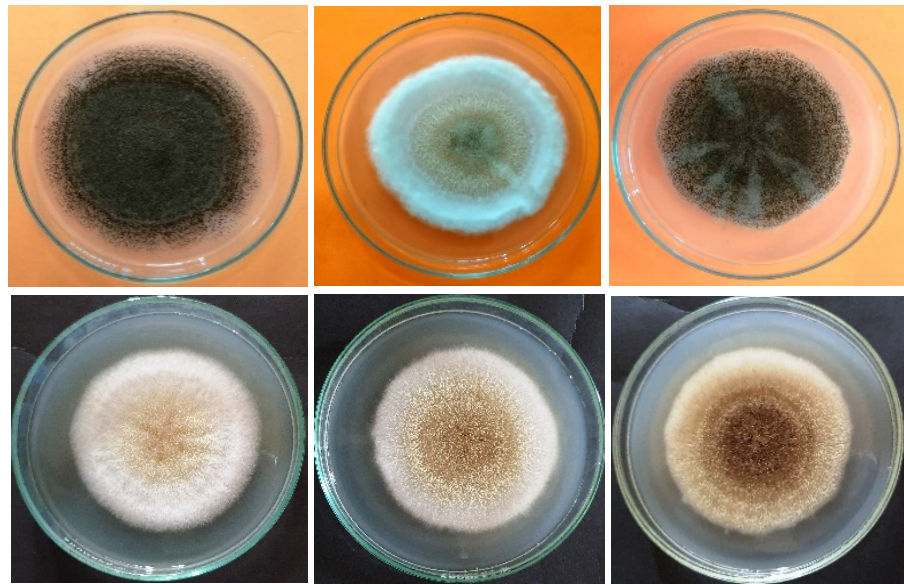

Figure 1. The growth of Aspergillus niger (from left ro right) BCCF194, Korbe 0909, and A1601 strains on solid Bunt and Rovira media containing quartz sand (above) and zeolite (below)

Gambar 1. Pertumbuhan Aspergillus niger strain (dari kiri ke kanan) BCCF194, Korbe 0909, dan A1601 di dalam media padat Bunt Rovira yang mengandung pasir kuarsa (atas) dan zeolit (bawah)
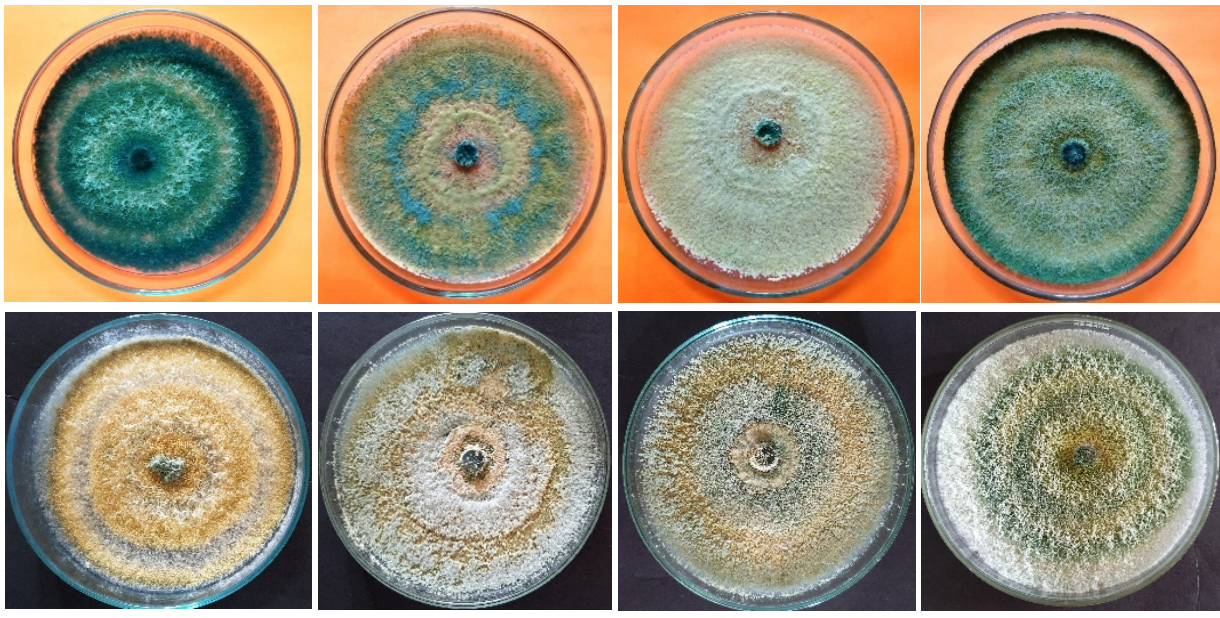

Figure 2. The growth of (from left to right) Trichoderma polysporum, T. Pseudokoningii, T. viride, and Trichoderma sp. on solid Bunt and Rovira media containing quartz sand (above) and zeolite (below)

Gambar 2. Pertumbuhan (dari kiri ke kanan) Trichoderma polysporum, T. Pseudokoningii, T. viride, and Trichoderma $s p$. di dalam media padat Bunt Rovira yang mengandung pasir kuarsa (atas) dan zeolit (bawah) 
(Aspergillus) and $\mathrm{R}^{2}=0.93-0.97$ (Trichoderma), respectively. Among the SSF in this research, $T$. polysporum has the highest ability in solubilizing silicate from quartz and zeolite. The significantly positive correlation at the level of $p<0.05$ between incubation time and the amounts of silica released from quartz and zeolite by $T$. polysporum were $\mathrm{R}^{2}=0.80$ and $\mathrm{R}^{2}=0.95$. All Aspergillus niger strains and Trichoderma species have potential capacity in solubilizing silica from magnesium trisilicate $\left(\mathrm{Mg}_{2} \mathrm{O}_{8} \mathrm{Si}_{3}\right)$ i.e.: $91.4-130.1 \mathrm{ppm}$, but showed poor in solubilizing silica from zeolite (17.6-19.4 ppm) and quartz (7.7-9.0 ppm). These phenomena suggested that silica solubilizing capacity depends on the type of mineral as source of silica. As reported by Klein \& Philpotts (2013) and Bai et al., (2019), quartz having a specific crystalline form, whereas zeolite have open pores in many different crystalline structures (Grismer \& Collison, 2017), thus physically and biologically resistant to weathering. Further, the lowest solubilizing silica in quartz and zeolite compared to magnesium trisilicate because crystalline quartz and zeolite will dissolve only very slowly in hot watery alkaline solutions. Hydroxyl ions primarily attack and subsequently break the stronger siloxane bonds (Si-O-Si) located on the surface of the silicone component (Ehrlich et al., 2010), while amorphous $\mathrm{SiO}_{2}$ in magnesium trisilicate will be readily dissolved at room temperatures.

\section{Effect organic acid on silica dissolution}

Production of organic acids is an important mechanism for solubilizing silicate from insoluble silicate from quartz sand and zeolite. According to Cuadros (2017), interaction of various microorganisms with the siliceous rocks takes place in three major ways: (i) bacteria and fungus solubilize silicate minerals by the secreted organic acids, (ii) microorganisms utilize silica by

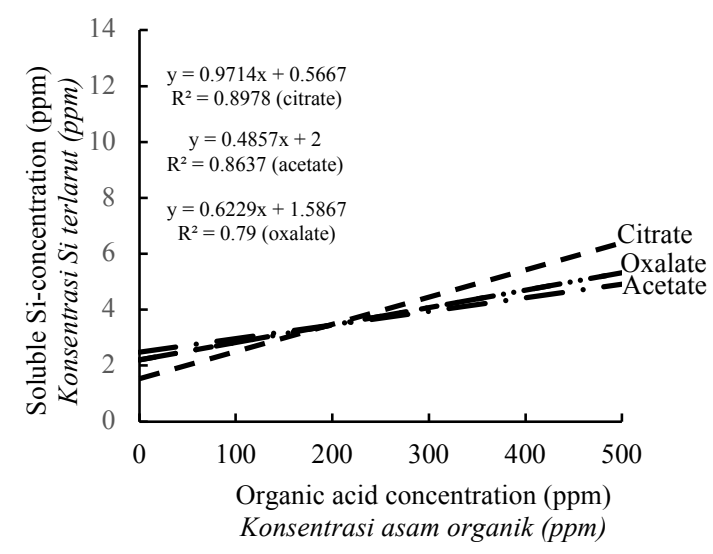

incorporating it into their cells, keeping it there for a period of time in an altered or unaltered condition, and then, releasing it into fermentation medium in the form of free silicic acid $\left(\mathrm{H}_{4} \mathrm{SiO}_{4}\right)$, and (iii) they also assimilate silica by taking it in dissolved form, polymerizing the same within the cells and thus silica becomes an integral part of the organism itself and is not released prior to death.

Fungi are known to play major role in dissolution of minerals like silicates (Lee et al., 2019). Several beneficial fungi have been reported for their positive impacts on plant under different stress conditions through better uptake of these minerals. Solubilization of insoluble silica due to organic acid production by fungi is known to enhance their availability to plants (Ameen et al., 2019). Various studies have reported weathering of silicates by bacteria for its dissolution to make it available to the plants (Chandrakala et al., 2019). From this study showed that the increased citrate, oxalate and acetate concentration in the modified Bunt and Rovira medium, apparently related to the significantly increased $(p<0.05)$ in available silica concentration in solution (Figure 3). It indicated that citrate has the strongest influence on the solubilization silica from quartz sand $\left(\mathrm{R}^{2}=0.89\right)$ and zeolite $\left(R^{2}=0.85\right)$. The result of the study suggested that the major mechanism of silica solubilization is due to the action of organic acids synthesized by SSF as reported by Bist et al. (2020) that the major mechanisms for the solubilization of silica by fungi is acidolysis. These phenomena lead to the assumption that citric acid is responsible for lowering the $\mathrm{pH}$ medium providing proton $\left(\mathrm{H}^{+}\right)$to increase the silica solubilization. There was relationship between the $\mathrm{pKa}$ values of the acids and the amounts of silica dissolution. Citric acid has a higher dissociation constant $(\mathrm{pKa}=3.14-6.40)$ than oxalic acid $(\mathrm{pKa}=$ $1.25)$ and acetic acid $(\mathrm{pKa}=4.75)$.

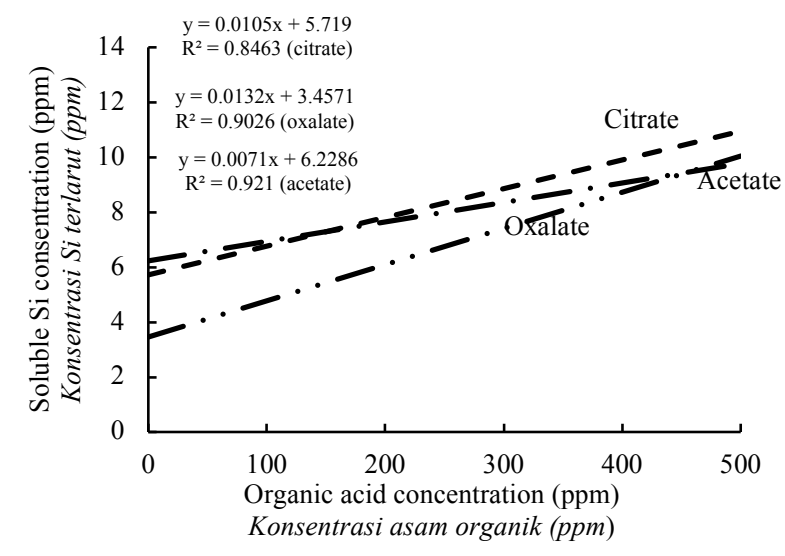

Figure 3. Correlation between concentration of selected organic acid (citrate, oxalate, and acetate) and solubilization of silica from quartz sand (left) and zeolite (right) in modified Bunt and Rovira liquid medium

Gambar 3. Hubungan antara konsentrasi asam organik (sitrat, oksalat, dan asetat) terhadap kelarutan silika dari sumber pasir kuarsa (kiri) dan zeolit (kanan) di dalam modifikasi medium cair Bunt dan Rovira 
Regarding the effect organic acid on silica dissolution, our study showed that Aspergillus and Trichoderma isolates produced acetic, citric, and oxalic acids in the presence of quartz and zeolite as silica sources in Bunt and Rovira liquid medium. Acetic acid was produced in higher amounts by Aspergillus and Trichoderma species than citric and oxalic acids (Table 3 ). However, further study is necessary to confirm the results particularly under different incubation time on organic acid production and its correlation between silica solubilizing capacity and organic acid production of the SSF.

\section{Effect of citric acid producing by SSF isolates on silica dissolution}

During our laboratory study, both Aspergillus and Trichoderma species produced high amount of citric acid, which is considered responsible for solubilization of silica originated from quartz and zeolite. There was significantly $(\mathrm{p}<0.05)$ positive correlation between citric acid production and incubation time by all of Aspergillus strain $\left(\mathrm{R}^{2}=0.85-0.99\right)$ and Trichoderma species $\left(\mathrm{R}^{2}=0.96-0.99\right)$, except isolates $T$. pseudokoningii $\left(\mathrm{R}^{2}=0.56\right)$ and $\mathrm{T}$. viride $\left(\mathrm{R}^{2}=0.44\right)$ in quartz as a source of silica (Figure 4-5). The highest citric acid production in Bunt and Rovira liquid medium by using quartz and zeolite as a silica sources in 12 days incubation was observed for $A$. niger BCCF194 i.e.: 889 ppm (quartz), 741.5 ppm (zeolite), and A. niger K0909 i.e.: 839 ppm (quartz) and $686.5 \mathrm{ppm}$ (zeolite). Whereas, $T$. polysporum 684 ppm (quartz) and 509 ppm (zeolite), Trichoderma sp. 751.5 ppm (quartz) and 589.0 ppm (zeolite). Similar result was reported by Makut \& Ekeleme (2018) that A. niger has higher potential in producing citric acid than Trichoderma isolate. Both silica dissolution and citric acid production have positive correlation with incubation time. The highest silica solubilizing capacity and citric acid produced by Aspergillus and Trichoderma species were achieved at 12 days incubation.

Table 3. The organic acids produced by SSF in modified liquid Bunt and Rovira medium using $\mathrm{Mg}_{2} \mathrm{O}_{8} \mathrm{Si}_{3}$, quartz, and zeolite as a silica sources after 8 days incubation time

Tabel 3. Produksi asam organik oleh fungi pelarut silika di dalam modifikasi medium Bunt dan Rovira dengan menggunakan $\mathrm{Mg}_{2} \mathrm{O}_{8} \mathrm{Si}_{3}$, kuarsa, dan zeolite sebagai sumber silika setelah 8 hari inkubasi

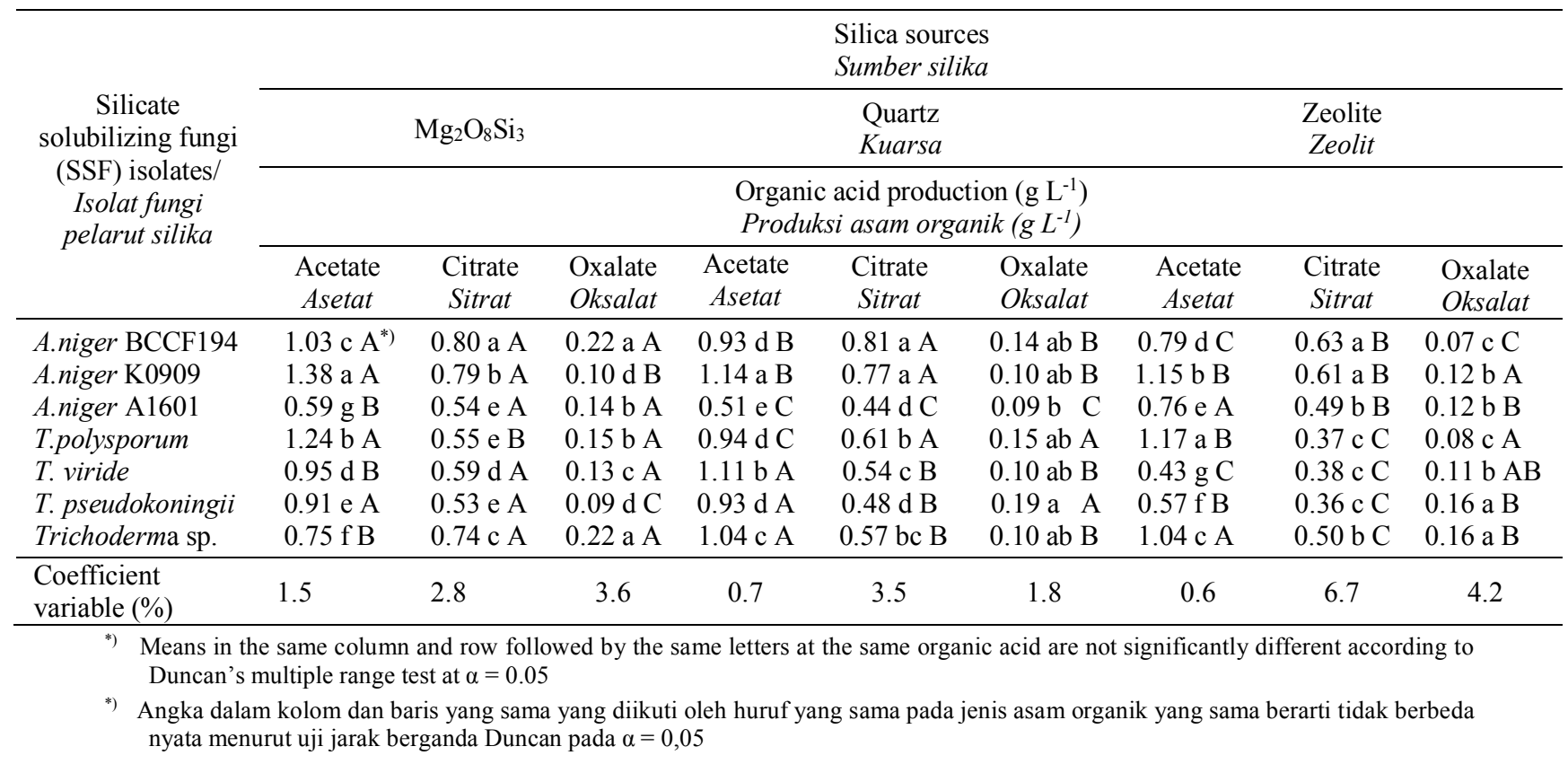



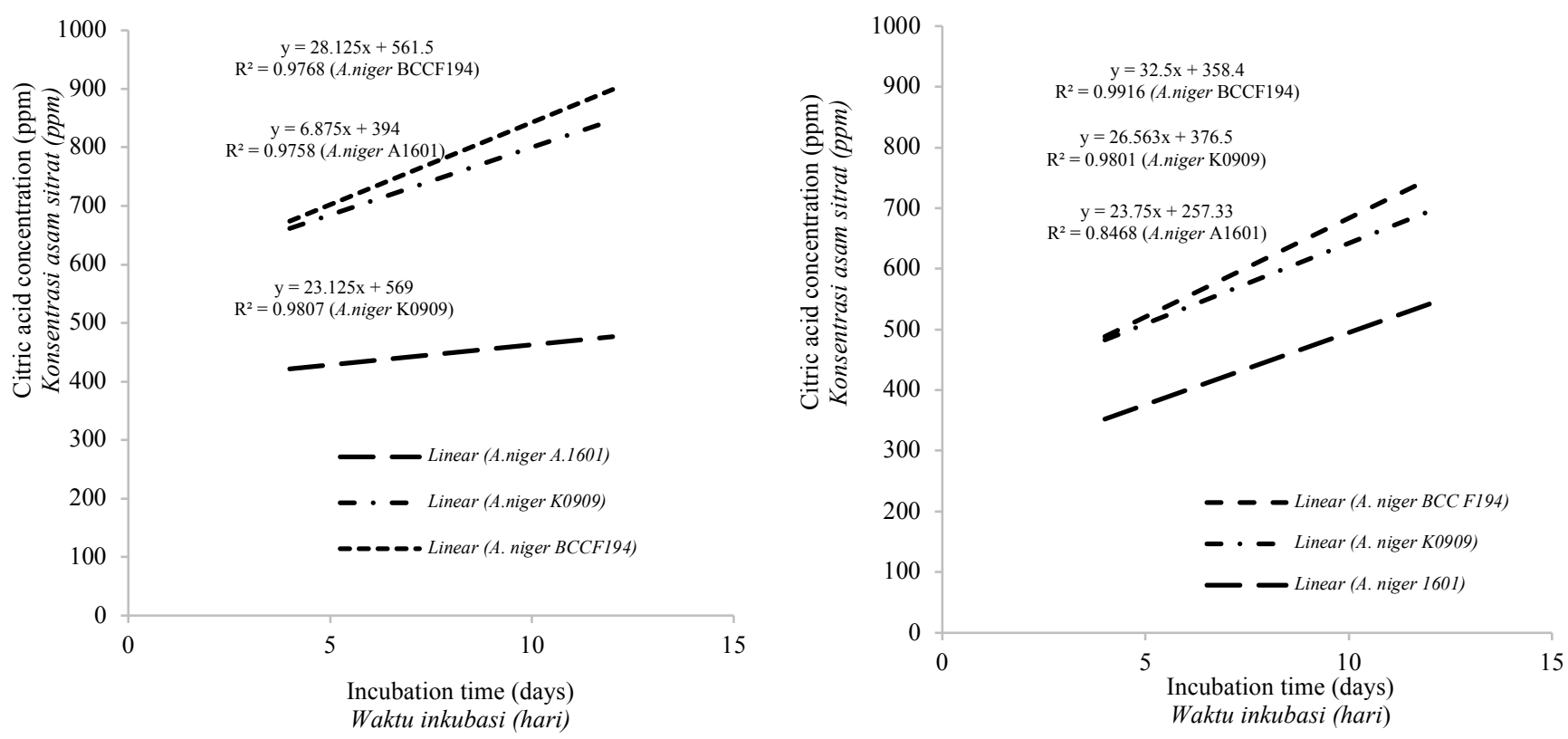

Figure 4. Correlation between citric acid production by A. niger strain and incubation time in Bunt and Rovira liquid medium containing quartz (left) and zeolite (right) as a silica source

Gambar 4. Hubungan antara produksi asam sitrat oleh strain A. niger terhadap waktu inkubasi di dalam medium cair Bunt dan Rovira yang mengandung pasir kuarsa (kiri) dan zeolit (kanan) sebagai sumber silika
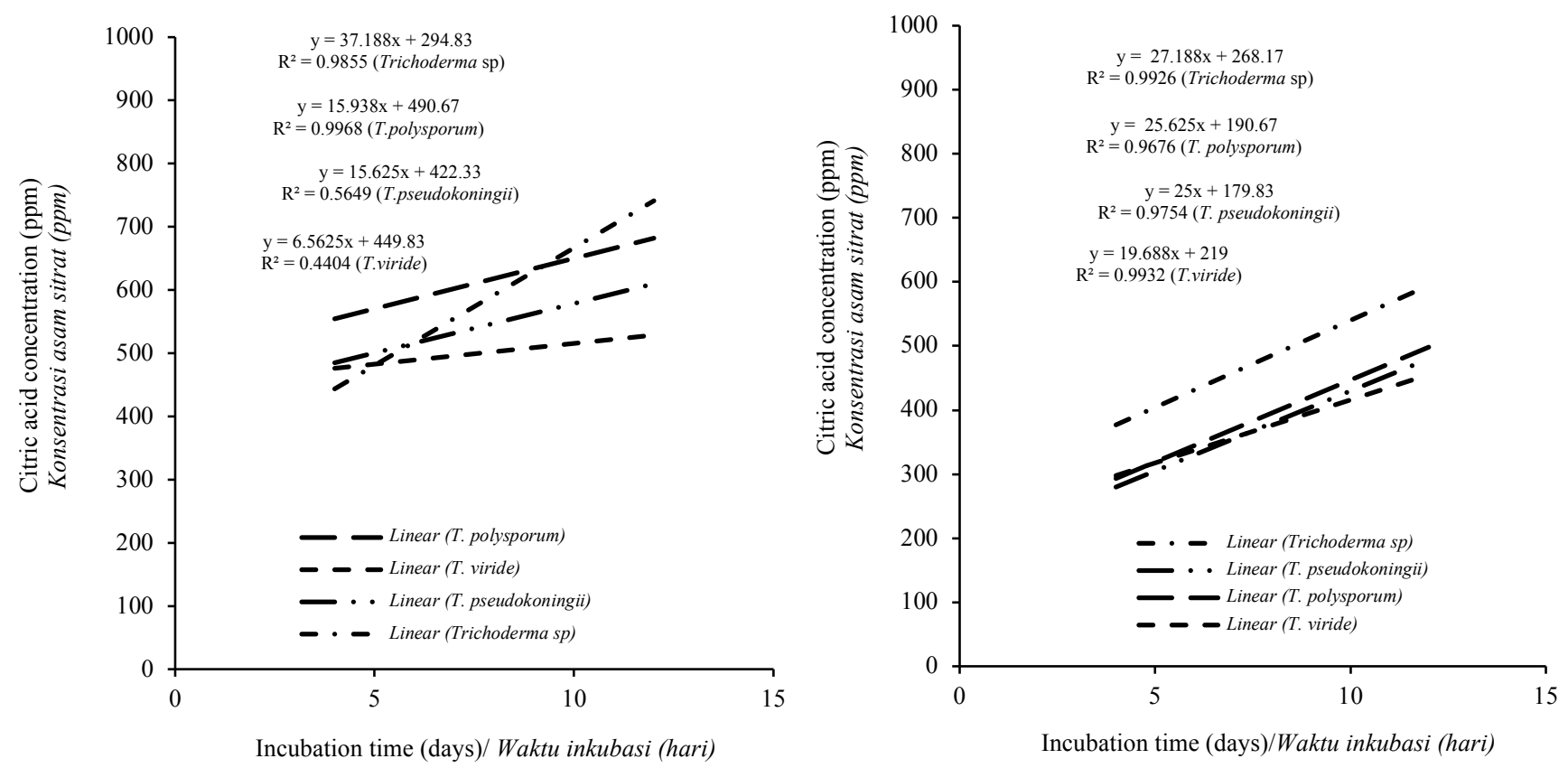

Figure 5. Correlation between citric acid production by Trichoderma isolates and incubation time in Bunt and Rovira liquid medium containing quartz (left) and zeolite (right) as a silica source

Gambar 5. Hubungan antara produksi asam sitrat oleh isolat Trichoderma terhadap waktu inkubasi di dalam medium cair Bunt dan Rovira yang mengandung pasir kuarsa (kiri) dan zeolit (kanan) sebagai sumber silika 


\section{Conclusion}

Trichoderma polysporum and A. niger BCCF194 isolates performed high abilities in solubilizing silica from quartz sand and zeolite. Both fungi were able to produce considerable amounts of organic acids (citrate, oxalate, and acetate) in the culture medium in the presence of quartz and zeolite as a silica source and these organic acids were important components responsible for silicate solubilization by Aspergillus and Trichoderma species. Acetic acid was the main organic acid produced by these species, but citric acid was more effective than oxalic and acetic acids in solubilizing silicate from quartz and zeolite. The amount of Si solubilized and citric acid produced by SSF were directly related to the incubation time.

\section{Acknowledgments}

The author wishes to thank The Indonesia Estate Crop Fund Management Agency for Palm Oil, for valuable supports in funding this research (Contract No. PRJ - 52 /BPDPKS/2016 and PRJ15/DPKS/2018).

\section{References}

Akintokun AK, GA Akande \& PO Akintokun (2007). Solubilization of insoluble phosphate by organic acid-producing fungi isolated from Nigerian soil. Int J Soil Sci 4, 301-307.

Ameen F, SA AlYahya, S AlNadhari, H Alasmari, F Alhoshani \& M Wainwright (2019). Phosphate solubilizing bacteria and fungi in desert soils: species, limitations and mechanisms. Arch Agron Soil Sci 65, 14461459.

Babu T, B Tubana, L Datnoff, J Yzenas \& Kanchan Maiti (2016). Release and sorption pattern of monosilicic acid from silicon fertilizers in different soils of Louisiana: A laboratory incubation study. Communications in Soil Science and Plant Analysis 47(12), 1559-1577.

Badan Standardisasi Nasional. SNI (Standar Nasional Indonesia) 13-3494-1994 (1994). Pengukuran kapasitas pertukaran kation mineral zeolit. National Standardization. Jakarta.

Badan Standardisasi Nasional. SNI (Standar Nasional Indonesia)15-0346-1989 (1989). Pasir kuarsa untuk pembuatan gelas tak berwarna, Mutu dan cara uji. National Standardization. Jakarta.

Bai R, YS Yi, \& LJ Yu (2019). Creating hierarchical pores in zeolite catalysts. Trends in Chemistry 1(6), 601-611.
Balakhnina T \& A Borkowska (2013). Effects of silicon on plant resistance to environmental stresses: Review. International Agrophysics 27, 225-232.

Bin L, X Leilei, \& S Qibiao (2019). Ecological effects of the microbial weathering of silicate minerals. Acta Geologica Sinica 91(1), 150152.

Bist V, A Niranjan, M Ranjan, A Lehri, K Seem \& S Srivastava (2020). Siliconsolubilizing media and its implication for characterization of bacteria to mitigate biotic stress. Front Plant Sci 28, 1-19.

Chandrakala C, SR Voleti, S Bandeppa, NS Kumar \& PC Latha (2019). Silicate solubilization and plant growth promoting potential of Rhizobium sp. isolated from rice rhizosphere. Silicon 11, $1-12$.

Chetan DM, SF Sarang, N Nithin, N Priyanka \& RS Bhat (2018). Comparison of citric acid production from Aspergillus niger in solid and suspension state fermentation. International Journal of Green Pharmacy 12(3), 502-509.

Cornelis JT, H Titeux, J Ranger \& B Delvaux (2011). Identification and distribution of the readily soluble silicon pool in a temperate forest soil below three distinct tree species. Plant Soil 342, 369-378.

Cuadros J (2017). Clay minerals interaction with microorganisms: a review. Clay Minerals 52, 235-261.

Daghino S, E Martino \& S Perott (2010). Fungal weathering and implications in the solubilization of metals from soil and from asbestos fibers. In: Mendez-Vilas A (ed) Current research, technology and education topics in applied microbiology and microbial biotechnology, vol 1, Microbiology book series, 2. Formatex Research Center, Badajoz, pp 329-338. ISBN: 9788461461943.

Ehrlich H, KD Demadis, OS Pokrovsky \& PG Koutsoukos (2010). Modern views on desilicification: Biosilica and abiotic silica dissolution in natural and artificial environments. Chem Rev 110, 4656-4689.

Etesami H, S Emami, \& HA Alikhani (2017). Potassium solubilizing bacteria (KSB): Mechanisms, promotion of plant growth, and future prospects - a review. J Soil Sci Plant Nutr 17(4), 897-911.

Goenadi DH \& LP Santi (2013). Biosuperphosphate (Bio-SP) application on sugarcane (Saccharum officinarum L.). Agrivita 35(1), 8-12. 
Grismer ME \& RS Collison (2017). The zeoliteanammox treatment process for nitrogen removal from wastewater-A Review. Water 9(11), 901.

Guntzer F, C Keller \& JD Meunier (2012). Benefits of plant silicon for crops: a review. Agronomy for Sustainable Development 32, 201-213.

Haynes RJ, ON Belyaeva \& G Kingston (2013). Evaluation of industrial wastes as sources of fertilizer silicon using chemical extractions and plant uptake. J Plant Nutr Soil Sci 176, 238248.

Heckman J (2013). Silicon: A Beneficial Substance. Better Crops 97(4), 14-16.

Jamal P, MZ Alam, M Ramlan, M Salleh \& MM Nadzir (2005). Screening of Aspergillus for citric acid production from palm oil mill effluent. Biotechnology 4(4), 275-278.

Kalbuadi DN, DH Goenadi, LP Santi \& LR Nurtjahja (2019). The potential use of natural clinoptilolite zeolite for crude oil spill removal from sea water. Journal of Minerals and Materials Characterization and Engineering 7, 446-453.

Kang SM, M Waqas, R Shahzad, YH You, S Asaf, MA Khan, KE Lee, GJ Joo, SJ Kim \& IJ Lee (2017). Isolation and characterization of a novel silicate solubilizing bacterial strain Burkholderia eburnea CS4-2 that promotes growth of japonica rice (Oryza sativa L. cv. Dongjin). Soil Science and Plant Nutrition 63(3), 233-241.

Karmollachaab A, A Bakhshandeh, MH Gharineh, TMR Moradi \& G Fathi (2013). Effect of silicon application on physiological characteristics and grain yield of wheat under drought stress condition. International Journal of Agronomy and Plant Production 4, 30-37.

Klein C \& AR Philpotss (2013). Earth Materials: Introduction to Mineralogy and Petrology. Cambridge University Press, United Kingdom.

Lee (2017). Isolation and characterization of a novel silicate solubilizing bacterial strain Burkholderia eburnean CS4-2 that promotes growth of japonica rice (Oryza sativa L. cv. Dongjin). Soil Science and Plant Nutrition 63(3), 233-241.

Lee K, A Adhikari, S Kang, Y You, G Joo, J Kim, S Kim \& I Lee (2019). Isolation and characterization of the high silicate and phosphate solubilizing novel strain Enterobacter ludwigii GAK2 that promotes growth in rice plants. Agronomy 9(144), 1-12.
Makut MD \& IK Ekeleme (2018). Citric acid production by Aspergillus niger and Trichoderma viride using hydrolysed potato peels substrate. Asian J Adv Agric Res 5(1), 17.

Marra LM, SM de Oliveira-Longatti, CRFS Soares, JM de Lima, FL Olivares \& FMS Moreira (2015). Initial $\mathrm{pH}$ of medium affects organic acids production but do not affect phosphate solubilization. Braz $J$ Microbiol 46(2), 367-375.

Naureen Z, M Aqeel, MN Hassan, SA Gilani, N Bouqellah, F Mabood, J Hussain \& FY Hafeez (2015). Isolation and screening of silicate bacteria from various habitats for biological control of phytopathogenic fungi. American Journal of Plant Sciences 6, 28502859.

Pei ZF, DF Ming, D Liu, GL Wan, XX Geng, HJ Gong \& WJ Zhou (2010). Silicon improves the tolerance to water-deficit stress induced by polyethylene glycol in wheat (Triticum aestivum L.) seedlings. Journal of Plant Growth Regulation 29, 106-115.

Rinder T \& EH Oelkers (2014). On the colorimetric measurement of aqueous $\mathrm{Si}$ in the presence of organic ligands and common $\mathrm{pH}$ buffering agents. Mineralogical Magazine 78(6), 1431-1436.

Santi LP \& DH Goenadi (2012). The potential use of bio-activated potassium-bearing mineral from East Java for $\mathrm{K}$ fertilizer. Menara Perkebunan 80(2), 1-7.

Santi LP \& DH Goenadi (2017). Solubilization of silicate from quartz mineral by potential silicate solubilizing bacteria. Menara Perkebunan 85(2), 96-104.

Santi LP, D Mulyanto \& DH Goenadi (2017). Double acid-base extraction of silicic acid from quartz sand. Journal of Minerals and Materials Characterization and Engineering 5(6), 362373.

Santi LP, N Haris \& D Mulyanto (2018). Effect of bio-silica on drought tolerance in plants. IOP Conf Ser: Earth Environ Sci, 183012014.

Schwartzman DW (2017). Life's critical role in the long-term carbon cycle: the biotic enhancement of weathering. AIMS Geosciences 3(2), 216-238.

Tubana BS, B Tapasya \& LE Datnoff (2016). A review of silicon in soils and plants and its role in US agriculture: history and future perspectives. Soil science 181(9), 393-411. 
Vasanthi N, LM Saleena \& SA Raj (2012). Silicon in day today life. World Applied Sciences Journal 17, 1425-1440.

Vasanthi N, LM Saleena \& SA Raj (2013). Evaluation of media for isolation and screening of silicate solubilising bacteria. Int J Curr Res 5(2), 406-408.

Vasanthi N, LM Saleena \& SA Raj (2018). Silica solubilization potential of certain bacterial species in the presence of different silicate minerals. Silicon 10, 267-275. 